\title{
Effect of The Addition of Casava Peel and Lactid Acid Bacteria As Feed Additives on The Chemical Profile of Broiler Chicken Meat
}

\author{
Arindya Ayu Perwitarini ${ }^{1}$, Edjeng Suprijatna ${ }^{1}$, dan Rina Muryani ${ }^{1}$ \\ ${ }^{1}$ Animal Husbandry and Agriculture Faculty, Universitas Diponegoro \\ Corresponding author : arindyadhea@gmail.com
}

\begin{abstract}
The purpose of this research is to evaluate the effect of feed additives in the form of a combination of cassava peel and BAL on the chemical profile of broiler chicken meat in the form of protein, cholesterol, LDL and HDL broiler chicken meat. The material used was 144 broiler day old chicken (DOC), feed (containing 18.9\% protein; $7.3 \%$ fat; $7.5 \%$ crude fiber; calcium $0.8 \%$; Phosphorus $0.7 \%$; energy metabolic (3044.9 kcal). This research used a completely randomized design with 4 treatments and 6 replications. T0 is a basal ration without the addition of feed additives (control); $\mathrm{T} 1$ is a basal ration $+50 \mathrm{ml} / \mathrm{kg}$ of feed additive; $\mathrm{T} 2$ is a basal ration $+100 \mathrm{ml} / \mathrm{kg}$ of feed additives and $\mathrm{T} 3$ is a basal ration $+150 \mathrm{ml} / \mathrm{kg}$ of feed additives. The results of the analysis of variance showed that the treatment of cassava peel and lactic acid bacteria affected the levels of meat protein and meat cholesterol but did not affect the levels of Low Density Lipoprotein (LDL) and High Density Lipoprotein (HDL) (P <0.05). Meat protein levels T0, T1, T2 and T3 respectively were $18.42 \% ; 18.35 \% ; 18.46 \%$ and $17.13 \%$. Cholesterol levels of meat T0, T1, T2 and T3 were $1.49 \mathrm{mg} / \mathrm{g} ; 1.43 \mathrm{mg} / \mathrm{g}$; $1.08 \mathrm{mg} / \mathrm{g}$ and $1.05 \mathrm{mg} / \mathrm{g}$. LDL levels of meat T0, T1, T2 and T3 were $0.32 \mathrm{mg} / \mathrm{g}$; $0.35 \mathrm{mg} / \mathrm{g} ; 0.37 \mathrm{mg} / \mathrm{g}$ and $0.37 \mathrm{mg} / \mathrm{g}$. HDL levels of meat T0, T1, T2 and T3 were $0.18 \mathrm{mg} / \mathrm{g} ; 0.16 \mathrm{mg} / \mathrm{g} ; 0.15 \mathrm{mg} / \mathrm{g}$ and $0.19 \mathrm{mg} / \mathrm{g}$. This study can be concluded that the addition of cassava peel can improve protein levels and reduce cholesterol levels but have not been able to improve LDL and HDL levels of broiler chicken meat.
\end{abstract}

Keywords: lactic acid bacteria, broiler, cholesterol, cassava peel, protein

\section{Introduction}

Broiler is an alternative livestock to meet the demands of the community for meat and has been cultivated in both small and large scale. Broilers have many advantages, namely having fast and efficient growth in turning food into meat, but broilers also have weaknesses, especially those related to health and sensitivity to disease (Tamalludin, 2014). Maintenance of broiler chickens in Indonesia has constraints of high temperature and humidity environment, resulting in heat stress on broiler chickens so that it can reduce the performance and growth of broiler chickens. Broiler chickens can grow well if supported by factors including food that concerns the quality and quantity, temperature during the maintenance period and maintenance related to the management system that is in the form of intensive maintenance patterns associated with feeding patterns, chicken health care and cleanliness of the cage (Rasyaf, 2003).

Prohibition of the use of antibiotics in Indonesia applies since January 1, 2018 which is regulated in Permentan No. 14 of 2017. Prohibition of the use of antibiotics is caused due to the negative impact of the presence of antibiotic residues in meat which 
causes health problems for consumers. For the sake of maintaining health, consumers also choose foods with low cholesterol content, while broilers have high fat and cholesterol content. Replacement of antibiotics with probiotics, prebiotics and synbiotics is expected to improve the quality of broiler chickens.

Probiotics are a number of microbes that can affect the composition of microflora in the digestive tract. The use of probiotics in poultry rations has been shown to improve the performance of broilers and laying hens (Iriyanti and Rimbawanto, 2001). Bacteria that can be used as probiotics are lactic acid bacteria (BAL) which can function to improve the balance of microorganisms in the digestive tract by inhibiting the growth of pathogenic bacteria (Trisna, 2012).

Prebiotics are food substances that cannot be digested by digestion and have a beneficial effect on the host through selective growth stimulation or activity against one or several types of microbes that benefit in digestion. Prebiotics mixed in the ration can be a beneficial food source for microbes in the digestive tract. Prebiotics and probiotics combined can cause a decrease in $\mathrm{pH}$ in the intestine so that pathogenic bacteria will not survive and lactic acid bacteria will increase so that absorption of nutrients in the intestine increases (Gabriela et al., 2005).

Probiotics and prebiotics are used in the form of lactic acid bacteria and cassava peel. Cassava peel is a result of processing of food made from cassava, cassava peel has a low protein content and high crude fiber and has antinutrient substances which can be detrimental to livestock if they are not processed first. The content of anti-nutrient substances in cassava peel, namely HCN, the processing in the form of soaking, washing and drying can help reduce HCN content in cassava skin (Akhadiarto, 2010). Cassava peel contains oligosaccharides in the form of inulin and sucrose which can be used as nutrients for microbial breeding so that they have the potential as prebiotics (Putra and Mardani, 2012).

Probiotics and prebiotics in the form of lactic acid bacteria and cassava peels are expected to help the development of broiler chickens become better, especially in the chemical content of meat from the broiler chickens. When prebiotics and probiotics are combined, it is expected to be able to increase protein levels in meat, reduce cholesterol and LDL levels and increase HDL levels in broiler chicken meat. The use of probiotics in the form of lactic acid bacteria has the advantage that BAL is a hypercholesterolemic prevention agent that can increase HDL levels and reduce LDL levels in broiler chicken meat (Astuti et al., 2015). In addition, the use of probiotics in the ration can help increase intestinal homeostasis which allows an increase in cholesterol degradation so that cholesterol levels decrease (David, 2006). Cassava peel as a prebiotic has a high content of crude fiber, which is expected to reduce cholesterol levels because the high content of crude fiber can help inhibit the process of fat absorption (Poendjiadi, 2005). This study aims to evaluate the effect of feed additives in the form of a combination of cassava peel and BAL on the chemical profile of broiler chicken meat in the form of protein, cholesterol, LDL and HDL broiler chicken meat.

\section{Materials and Methods}

This research was conducted in December 2018 - January 2019 at the Poultry Production Laboratory, Animal Husbandry and Agriculture Faculty, Universitas Diponegoro, Semarang. Protein analysis was carried out at the Chemistry and Nutrition 
Laboratory, Faculty of Animal Husbandry and Agriculture, Universitas Diponegoro Semarang. Cholesterol, LDL and HDL analyzes were carried out at the Nutrition and Feed Laboratory, Animal Husbandry and Agriculture Faculty, Universitas Diponegoro Semarang.

\section{Materials}

The material is used 144 broiler day old chicken (DOC) with strain MB 202. The ingredients used in the ration feed were corn, rice bran, fish meal, soybean meal, meat bone meal (MBM), premix, $\mathrm{CaCO}_{3}$. Feed additives used in the form of a combination of cassava peel flour obtained from the Salatiga D-9 Cheese Cassava factory and lactic acid bacteria isolated from the digestive tract of ducks. The composition of the ration and the nutritional content of the ration can be seen in Tables 1 and 2. as follows:

Table 1. Composition of Broiler Chicken Basal Rations

\begin{tabular}{lrc}
\hline \hline \multirow{2}{*}{ Feed ingredients } & \multicolumn{2}{c}{ Compositions $(\%)$} \\
\cline { 2 - 3 } & Starter & Finisher \\
\hline Corn & 45.55 & 50 \\
Bran & 15.65 & 20 \\
Fish Meal & 7 & 7 \\
Soybean Meal & 25.80 & 17 \\
MBM & 3 & 3 \\
Premix & 1 & 1 \\
CaCo3 & 2 & 2 \\
\hline Total & 100 & 100 \\
\hline
\end{tabular}

Table 2. Nutrient Content of Broiler Chicken Rations

\begin{tabular}{|c|c|c|c|c|c|c|c|c|}
\hline \multirow{2}{*}{$\begin{array}{l}\text { Nutrient } \\
\text { Content }\end{array}$} & \multicolumn{4}{|c|}{ Starter } & \multicolumn{4}{|c|}{ Finisher } \\
\hline & T0 & T1 & $\mathrm{T} 2$ & T3 & T0 & T1 & $\mathrm{T} 2$ & T3 \\
\hline $\begin{array}{l}\text { Metabolic } \\
\text { Energy } \\
(\mathrm{kkal}) * *\end{array}$ & 3025.23 & 3038.08 & 3046.48 & 3054.41 & 3044.91 & 3057.18 & 3065.04 & 3072.46 \\
\hline $\begin{array}{l}\text { Crude } \\
\text { Protein } \\
(\%)^{*}\end{array}$ & 22.27 & 21.77 & 21.29 & 20.83 & 18.99 & 18.58 & 18.19 & 17.82 \\
\hline $\begin{array}{l}\text { Crude Fat } \\
(\%)^{*}\end{array}$ & 6.67 & 6.55 & 6.41 & 6.28 & 7.35 & 7.20 & 7.05 & 6.90 \\
\hline $\begin{array}{l}\text { Crude Fiber } \\
(\%)^{*}\end{array}$ & 7.10 & 7.19 & 7.27 & 7.35 & 7.60 & 7.67 & 7.74 & 7.80 \\
\hline $\begin{array}{l}\text { Calcium } \\
(\%)^{*}\end{array}$ & 0.87 & 1.47 & 1.44 & 1.41 & 0.84 & 1.44 & 1.42 & 1.38 \\
\hline $\begin{array}{l}\text { Phospor } \\
(\%)^{*}\end{array}$ & 0.71 & 0.71 & 0.69 & 0.67 & 0.72 & 0.73 & 0.71 & 0.70 \\
\hline
\end{tabular}

\section{Methods}




\section{- Making cassava peel flour}

Cassava peel flour is made by separating cassava peel from the skin, then washed thoroughly and cut into smaller sizes $(3-5 \mathrm{~cm})$ and then dried in the sun for 3 days to dry, after dry, the cassava peel is ground to become flour.

\section{- Manufacture of the feed additives}

Making probiotics is done by isolating BAL from the duck intestine in the caecum section along $\pm 10 \mathrm{~cm}$. Then the process of incubation and BAL culture was carried out so as to obtain the final yield of lactic acid bacteria broodstock of $2.3 \times$ $108 \mathrm{CFU} / \mathrm{ml}$. The next step is to determine the optimal prebiotic content as a food additive by mixing $4 \%$ ( 0.4 gram) cassava peel, 5\% (0.5 gram) and 6\% (0.6 gram) and then each mixed with probiotics. consisted of $10 \mathrm{ml}$ of distilled water plus $1 \mathrm{ml}$ of lactic acid bacteria culture then incubated for 24 hours at $37^{\circ} \mathrm{C}$. Then dilution is carried out and the highest yield is $6.5 \times 109 \mathrm{CFU} / \mathrm{ml}$. Prebiotics that produce the highest CFU (6\%) 0.6 grams were selected as prebiotics. The incorporation of feed additives was carried out by means of $10 \mathrm{ml}$ of probiotics added with $100 \mathrm{ml}$ of distilled water and $6 \%$ cassava peel and then incubated for 24 hours. The next step is to test the survival of the bacteria in the ration by synbiotic dispray in the ration and then observe the bacteria every 4 hours and 12 hours and get the results of bacterial resistance for 26 hours.

\section{- The step of applying the treatment into the ration.}

The treatment of the addition of cassava peel and lactic acid bacteria was carried out when the broiler chickens were 11 days to 38 days old. Provision of feed additives is done by pouring and mixed evenly in chicken feed and given in the morning as much as $20 \%$ of the chicken needs every day.

The treatment of broilers is:

T0: Feeding in the form of basal ration without addition

$\mathrm{T} 1$ : Feeding in the form of basal ration $+50 \mathrm{ml} / \mathrm{kg}$ feed additive

T2: Feeding in the form of basal ration $+100 \mathrm{ml} / \mathrm{kg}$ feed additive

T3: Feeding is in the form of basal ration $+150 \mathrm{ml} / \mathrm{kg}$ feed additive

\section{- Data Collection Phase}

The step of data collection is done by taking a sample of 1 animal from each randomized random sampling unit. Conduct carcass quality inspection analysis by carcassing. Then do the chemical test of meat by taking 30 grams of meat on the chest and thighs. Meat chemical testing in the form of protein content was carried out by the Micro-Kjeldhal method. Tests of cholesterol, LDL and HDL content in meat were carried out at the Nutrition and Feed Laboratory using the Cholesterol Oxidase Phenol Aminoantipyrin (CHOD-PAP) method with a spectrophotometer. Meat samples were weighed as much as 4 grams into an erlemeyer tube, then added with $10 \mathrm{ml}$ prpanol and $\mathrm{KOH}$ in $2 \mathrm{ml}$ methanol. Then saponification using a water bath with a temperature of $80^{\circ} \mathrm{C}$ for 30 minutes. Then chill for 15 minutes and filtered so that a clear liquid is obtained which will then be tested by adding $2 \mathrm{ml}$ of cholesterol KIT, wait 10 minutes then measuring absorbance (ABS) samples using a spectrophotometer. The cholesterol content of meat is calculated by the following formula: 
Cholesterol Concentration $=\frac{\text { ABS Sampel }- \text { ABS Blanko }}{\text { ABS Standar }} \times 200$

Air Dry Levels $(\mathrm{KU}) \quad=\frac{\text { Concentration } \times(2 / 100) \times(0,2 / 0,02)}{\text { Sample of Weight }}$

Fresh concentration $(\mathrm{mg} / \mathrm{g})=\frac{100-\text { Water content }}{100} \times$ Level of $\mathrm{KU}$

The LDL content of meat is calculated by the following formula:

Concentration LDL $\quad=\frac{\text { ABS Sampel }}{\text { ABS Standar }} \times 20$

Level of LDL $=$ Cholesterol concentration - Concentration of LDL

Air Dry Levels $(\mathrm{KU}) \quad=\frac{\text { Concentration } \times(2 / 100) \times(1 / 0,2)}{\text { Sample of Weight }}$

Fresh concentration $(\mathrm{mg} / \mathrm{g})=\frac{100-\text { Water content }}{100} \times$ Level of KU

The meat HDL content is calculated by the following formula:

Concentration HDL = (Abs Sampel - Abs Blangko $) \times 188$

Air Dry Levels $(\mathrm{KU}) \quad=\frac{\text { Concentration } \times(2 / 100) \times(1 / 0,2)}{\text { Sample of Weight }}$

Fresh concentration $(\mathrm{mg} / \mathrm{g})=\frac{100-\text { Water content }}{100} \times$ Level of $\mathrm{KU}$

\section{- Experimental design}

The experimental design that is used a completely randomized design (CRD) with 4 treatments and 6 replications with each experimental unit consisting of 6 broilers.

\section{- Data analysis}

The data obtained were then analyzed using ANOVA analysis of variance, tested by the $\mathrm{F}$ test level of $5 \%$ to determine the effect of the experiment, if there is an influence then continued with the duncan test with a level of 5\%. Data analysis was assisted with the SAS program. 


\section{Results and Discussion}

The results of the research of protein levels, cholesterol levels, Low Density Lipoprotein (LDL) and High Density Lipoprotein (HDL) levels due to the addition of cassava peel and lactic acid bacteria in broiler chicken feed can be seen in Table 3 . as follows:

Table 3. Chemical Content of Broiler Chicken Meat

\begin{tabular}{lcccc}
\hline \multirow{2}{*}{\multicolumn{1}{c}{ Parameter }} & \multicolumn{4}{c}{ Treatment } \\
\cline { 2 - 5 } & T0 & T1 & T2 & T3 \\
\hline Meat Protein $(\%)$ & $18.4252^{\mathrm{a}}$ & $18.3517^{\mathrm{a}}$ & $18.4647^{\mathrm{a}}$ & $17.1317^{\mathrm{b}}$ \\
Meat Cholesterol $(\mathrm{mg} / \mathrm{g})$ & $1.4894^{\mathrm{a}}$ & $1.4321^{\mathrm{a}}$ & $1.0821^{\mathrm{b}}$ & $1.0499^{\mathrm{b}}$ \\
LDL of Meat $(\mathrm{mg} / \mathrm{g})$ & 0.32475 & 0.35165 & 0.36608 & 0.37283 \\
HDL of Meat $(\mathrm{mg} / \mathrm{g})$ & 0.17755 & 0.16525 & 0.15438 & 0.19415 \\
\hline
\end{tabular}

Different superscripts on the same line show significant differences $(\mathrm{P}<0.05)$

\section{Protein of The Meat}

The results of the research due to the addition of cassava peel and lactic acid bacteria as feed additives to the protein content in broiler chicken meat are listed in Table 3. The results of the analysis of variance showed that there was a significant effect $(\mathrm{P}<0.05)$ on the treatment of reducing meat protein levels. Significant reduction was found in the T3 treatment, while the T1 and T2 treatments did not differ from the T0 treatment. The results of this research are inversely proportional to the research of Nuningtyas (2014), that the use of prebiotics in the form of garlic flour has significantly increased results on the protein content of broiler chicken meat, this is due to protein consumption and increased protein digestibility. Research of Wiryawan et al. (2005) about the use of probiotics in the form of EM4 get results that have the effect of increasing the consumption of feed, digestibility and protein in broiler chickens.

The protein content of the meat in broiler chickens from the results of the study showed figures between $17.13-18.46 \%$. The protein content is included in the normal numbers, according to Sukarini et al. (2004) protein content of broiler chicken meat shows the figure 16-22\%. The treatment of the addition of cassava peel and lactic acid bacteria as a food additive does not affect the meat protein content can be caused by factors such as protein content in the ration. The protein content in the ration used shows a lower number in the treatment of additives with higher levels. According to Kartikasari et al. (2001), the protein content in meat can be influenced by several factors, one of which is the protein content in the ration.

The treatment of adding cassava peel and lactic acid bacteria as feed additives to the ration which is expected to increase meat protein content, turned out to give the opposite result. This can be caused by the small oligosaccharide content in prebiotics $( \pm$ $5.43 \%$ ). The oligosaccharide content in prebiotics will support the growth of BAL which will cause acidic conditions in the digestive tract. According to Suthama (2003), acidic digestive conditions due to pathogenic bacteria cause better digestion. Acidic atmosphere in the digestive tract can increase protein digestibility and can increase the work of protease enzymes, increased protein digestibility can support growth and increase protein content in meat. 


\section{The Meat Cholesterol}

The results of the research to the addition of cassava peel and lactic acid bacteria as feed additives in broiler chickens showed the average cholesterol levels in broiler chicken meat are listed in Table 3. The results of the analysis of variance showed that there was a significant effect $(\mathrm{P}<0.05)$ treatment on the reduction meat cholesterol level. Significant decreases were found in T2 and T3 treatments, whereas T1 treatments did not differ from T0 treatments. This is presumably due to the presence of high crude fiber content in prebiotics and the presence of lactic acid bacteria as probiotics in rations which causes cholesterol levels in meat to decrease.

The research of Ibrahim et al. (2015), states that the use of prebiotics in the form of pineapple skin combined with Lactobacillus get results that have a significant effect on meat cholesterol levels, meat cholesterol levels obtained are not much different, namely $1.42-1.52 \mathrm{mg} / \mathrm{g}$. Based on Daud's (2006) research on probiotics in the form of Bacillus sp. and prebiotics in the form of katuk leaves with probiotic levels of $0.2 \%$ and prebiotics $0.5 \%$, causing a significant decrease in cholesterol levels in broiler chicken meat that is equal to $0.36 \mathrm{mg} \%$. This is due to the presence of anti-bacterial properties in katuk leaves which can kill harmful microorganisms so that the growth of beneficial bacteria can be increased, so that the absorption of nutrients is better.

The cholesterol content of meat in broiler chickens from the results of the study showed figures between $1.0499-1.4894 \mathrm{mg} / \mathrm{g}$. Cholesterol content in chicken meat based on research results is lower (better) compared to existing standards. According to Massolo et al. (2009) broiler chickens have high cholesterol content which is $2 \mathrm{mg} / \mathrm{g}$.

The treatment of the addition of cassava peel and lactic acid bacteria as feed additives shows the result that there is a decrease in cholesterol of broiler chicken meat, this is caused by the presence of inhibited fat digestion due to the high crude fiber content in feed originating from cassava skin. According to Poendjiadi (2005) when the crude fiber content in broiler chicken feed is high, what happens is that the crude fiber will bile bile acids as soon as it reaches the digestive tract, causing the function of bile to help absorb fat.

Impaired fat absorption or a decrease in lipase activity will cause a decrease in cholesterol content in broiler chicken meat. The existence of probiotics in a given ration can help influence the activity of enzymes that can help reduce cholesterol levels. Besides that, according to Syafrizal et al. (2018) the use of probiotics can increase intestinal homeostasis which enables the mechanism of cholesterol destruction or degradation by digestive tract microorganisms by converting cholesterol to kholat bile acids, so cholesterol levels decrease.

\section{LDL and HDL of Meat}

The results of the research due to the addition of cassava peel and lactic acid bacteria as feed additives in broiler chickens showed the average levels of LDL and HDL in broiler chicken meat listed in Table 3. The results of the analysis of the variance showed that there was no significant effect $(\mathrm{P}>0.05)$ treatment of LDL and HDL levels. This can be caused by low oligosaccharide content and undeveloped lactic acid bacteria. This research is inversely proportional to the results of the research of Syafrizal et al. (2018) using prebiotics in the form of oil palm cake which showed significant results on LDL and HDL meat with a concentration of $4 \%$. 
The addition of cassava peel and lactic acid bacteria as feed additives showed insignificant results on LDL and HDL of broiler chicken meat. The LDL content of meat in broiler chickens from the results of the study showed a number between $0.32475-0.37283 \mathrm{mg} / \mathrm{g}$. The HDL content of meat in broiler chickens from the results of the study showed a number between $0.15438-0.19415 \mathrm{mg} / \mathrm{g}$.

The insignificant LDL and HDL levels of broiler chicken meat can be caused by oligosaccharide content that is still too low that it is unable to support microbes to grow. Oligosaccharides are nutrients that are used as food from microbes. Haryati (2011) states that the oligosaccharides contained in prebiotics are directly utilized by beneficial microbes as substrates to support their life and activities.

High fat in the body will cause an increase in LDL levels, namely lipoprotein which is rich in cholesterol. Syafrizal et al. (2018) states that high fat will cause an increase in LDL levels in broiler chicken meat, if more fat is released by the body, LDL levels in the body will decrease and HDL levels in the body will increase. The use of probiotics in chicken rations can reduce LDL levels in broiler chicken meat.

According to Abdurrahman and Yanti (2018) probiotics can fernent against inulin which can produce metabolites in the form of acetate, butyrate and propionate which can inhibit the process of lipogenesis in the liver so that the level of meat fat decreases and is followed by decreasing levels of meat LDL. According to Tanewo et al. (2010). the lower the LDL level, the better it is because if high LDL levels will cause the deposition of cholesterol in meat, the cause of the decrease in LDL is due to the presence of excess fiber content so that cholesterol can be inhibited and LDL levels will decrease. A decrease in LDL levels will be followed by an increase in HDL levels caused by the accumulation of unused cholesterol. High HDL can transport free cholesterol found in the tissues to the HDL receptors in the liver which will then be excreted through bile.

\section{Conclusion}

The results of the research concluded the addition of cassava peel and lactic acid bacteria in broilers at a dose of $50 \mathrm{ml} / \mathrm{kg}, 100 \mathrm{ml} / \mathrm{kg}$ and $150 \mathrm{ml} / \mathrm{kg}$ can reduce meat cholesterol levels but have not been able to increase meat protein levels and have not been able to improve HDL and LDL levels of broiler chicken meat.

\section{References}

Abdurrahman, Z. H. dan Y. Yanti. 2018. Gambaran umum pengaruh probiotik dan prebiotik pada kualitas daging ayam. J. Ternak Tropika. (19) $2: 95$ - 104.

Akhadiarto, S. 2010. Pengaruh pemanfaatan limbah kulit singkong dalam pembuatan pellet ransum unggas. J. Teknologi Lingkungan. 11 (1) : 127 - 138.

Astuti, F. K., W. Busono dan O. Sjofjan. 2015. Pengaruh penambahan probiotik cair dalam pakan terhadap penampilan produksi pada ayam pedaging. J. PAL. 6 (2) : $99-104$.

Daud, M. 2006. Persentase dan kualitas karkas ayam pedaging yang diberi probitoik dan prebiotik dalam ransum. J. Ilmu Ternak. 2 (6) : $126-131$. 
Gabriela, C. R. R., I. M. Pop dan D. Simean. 2005. Effect of a symbiotic feed additive supplementation on laying hens performance and eggs quality. Br. Poult. Sci. 53: $89-93$.

Haryati, T. 2011. Probiotik dan prebiotik sebagai pakan imbuhan non ruminansia. Wartazoa. 21 (3) : $125-132$.

Ibrahim, W., R. Mutia dan Nurhayati. 2015. Penggunaan kulit nanas fermentasi dalam ransum yang mengandung gulma berkhasiat obat terhadap lemak dan kolesterol ayam broiler. J. Agripet. (14) $1: 20-27$.

Iriyanti, N. dan E. A. Rimbawanto. 2001. Inokulasi probiotik lactobacillus sp. Asal ayam buras sebagai upaya perbaikan performans ayam petelur.Laporan Penelitian.Fakultas Peternakan Universitas Jenderal Soedirman. Purwokerto.

Kartikasari, L. R., Soeparno dan Setiyono. 2001. Komposisi kimia dan studi asam lemak daging dada ayam broiler yang mendapat suplementasimetionin pada pakan berkadar protein rendah. Buletin Peternakan. 25(1) : $33-39$.

Massolo, R., A. Mujnisa dan L. Agustina. 2009. Persentase karkas dan lemak abdominal broiler yang diberi prebiotik inulin umbi bunga Dahlia (Dahlia variabillis). Buletin Nutrisi dan Makanan Ternak. 12(2) : 50 - 58.

Nuningtyas, Y. F. 2014. Pengaruh penambahan tepung bawang putih (Allium sativum) sebagai aditif terhadap penampilan produksi ayam pedaging. J. Ternak Tropika. $1(15): 21-30$.

Poendjiadi, A. 2005. Dasar-dasar Biokimia. UI Press. Jakarta.

Rasyaf, M. 2003. Makanan Ayam Broiler. Kanisius, Yogyakarta.

Siswohardjono, W. 1982. Beberapa Metode Pengukuran Energi Metabolis Bahan Makanan pada Itik. Makalah Seminar Fakultas Pascasarjana. Institut Pertanian Bogor, Bogor.

Sukarini, N. E., L. D. Mahfudz dan A. M. Legowo. 2004. Pengaruh penggunaan ampas kecap yang diproses dengan larutan asam asetat untuk pakan terhadap komposisi kimia daging dada ayam broiler (The usage effect of acetic acid-processed soy souce waste in a ration to chemical composition of broiler breast). J. Indon. Trop. Anim. Agric. 29 (3) : 129 - 138.

Suthama, N. 2003. Metabolisme protein pada ayam kampung periode pertumbuhan yang diberi ransum memakai dedak padi fermentasi. J. Pengemb. Pet. Trop. 1(1) : $44-48$.

Syafrizal, Nurliana dan Sugito. 2018. Pengaruh pemberian ampas kedelai dan bungkil inti sawit (AKBIS) yang difermentasi dengan Aspergillus niger terhadap kadar lemak dan kolesterol daging dada broiler. J. Agripet. 18(2) $74-82$.

Tamalludin, F. 2014. Ayam Broiler. Penebar Swadaya, Yogyakarta.

Tanewo, M., A. Paga dan B. Hadisusanto. 2010. Status hematologis broiler yang diberikan tepung sangria biji asam tanpa kulit. J. Kajian Veteriner. 1 (3) : $43-51$. 
Trisna, W. N. 2012. "Identifikasi Molekuler dan Pengaruh Pemberian Probiotik Bakteri Asam Laktat (BAL) Asal Dadih dari Kabupaten Sijunjung Terhadap Kadar Kolestrol Daging pada Itik Pitalah Sumber Daya Genetik Sumatra Barat”. Artikel Ilmiah Peternakan. Universitas Andalas.

Wiryawan, K. G., M. Sriasih dan I. D. P. Winata. 2005. Penampilan ayam pedaging yang diberi probiotik (EM4) sebagai pengganti antibiotik. Majalah Ilmiah Peternakan. (1) $1: 1-10$. 